\title{
Successful Reasons for Building up a New Order After Revolution —— An Investigation on Hannah Arendt's Political Thought in On Revolution
}

\author{
Jiang Qirui1, a \\ ${ }^{1}$ Department of Government and Public Administration, Chinese University of Hong Kong, Hong Kong \\ amaolenin217@163.com
}

\begin{abstract}
As the crises happened in political area became much more frequently and intensely in recent decades, there are more and more people starting to reflect on the legitimacy of the modern politics. They wish to diagnose the diseases of our era and give their own prescriptions. Hannah Arendt was one of the greatest one in these thinkers. Since she started her political thinking, the modernity had been in her core topics in a very long time. On Revolution, her book published in 1963, was one of her prescriptions to solve the problems. This article would talk about the positive factors she considered the American Revolution had revealed in building up a new Constitution for freedom and those negative factors she thought that led the French Revolution fell into failure. Through filtering out these core factors from her majestic and complex articulation, we can have a clearer picture of what kind of new order was praised by her. Then, we will also point out the problems inside her articulation about the new order to have a deeper understanding of her reflection on the political reality.

Keywords: Hannah Arendt, revolution, public freedom, new political order
\end{abstract}

\section{INTRODUCTION}

In now days, the political situation around the world actually ran into a kind of strait. In the western democratic countries, the representative system faces the crisis of confidence, some people described it as a tool of big capitals [1]. While, indeed, people's trust to the power institutions keeps falling in decades, e.g., the American congress's positive image on people have fallen $40 \%$ percent from 1985 to 2015 [2]. In the non-western democratic countries, the governments are facing the troubles of social protests and democratic movements. For example, in Arabic world, the so-called Arab Spring set off a huge wave to the traditional political regimes and caused many coups in those countries [3]. All these situations in some way remind us that the regimes in current era are imposed to duel with the legitimacy of themselves. Facing people's displeasure or even opposition to them, they must find some solutions to prove or reacquire their legitimacy. Therefore, the question of "what is a good regime?" becomes important again in the current context, which has been one of the core issues in political philosophy, especially during the classical era, for a very long time. Thus, referring back to those important philosophers who had critical articulations on that question has rejuvenated. Hannah Arendt, as one of the most important political thinkers in contemporary political philosophy, had also made a great effort in this field. One of her core articulations is politics was to build up a collective system, in which people are not only able to vote, but also could attend the discussions and take actions of the political issues [4]. In this way, her theory on democracy was not same with the storytelling in mainstream. This is could be seen as the result of her different understanding of politics from the traditional ruling-ruled model, which is still the inner pattern of current political order around the world [5]. Thus, the way that she considered the new political order should be valuable for our reflections in now days.

Her book, On Revolution, may be the one that mostly focusing on what contributed to the ideal order that she considered could totally fulfill human's freedom. Firstly, she considered that the only possible way of violent conflict in future would be revolution. In her mind, due to the destroying power of the weapons, the war under the aim of conquest between huge powers became less and less possible, which left a relative stable situation on international relations. In this situation, the only reasonable reason of war is to be the lead of those revolutions fighting for freedom [6]. So, the conflicts would become opportunity suppliers for building up new order in the future. Secondly, maybe as a kind of preparation for this future, she put this book under the aim of finding out what experience those successful revolutions would encourage us, and those failed ones would admonish us [7]. In the main part of the book, she had compared the reasons why American reached the glorious ending of building up a Constitution that was able to maintain freedom and the reasons why French Revolution finally missed the critical moment to build up a polity for freedom. During this process, she illustrated the important positive factors and negative ones in building up a new state after revolution. From On Revolution, we have summarized two positive factors and three negative factors for building up freedom. The positive ones are implementation of public freedom and obtaining political authority from founding moment. The negative ones are remaining of absolute Tradition, 
misusing of compassion and the highlighting of the private happiness. In this article, we would illustrate how Arendt raised and demonstrated these factors. Besides, as in some part, she did not give a specific articulation, we would go to her other materials to make up the demonstration. By the way, we would not only retell her articulation, but would also have some reviews and further thinking on her "ideal state".

\section{DISCUSSION}

\subsection{Positive Factors for Building up a State after Revolution: Implementation of Public Freedom and Political Authority from Founding Moment}

\subsubsection{Implementation of Public Freedom}

The first positive factor showed by the American Revolution was the implementation of public freedom. The idea of public freedom was a common thing that shared by both coasts of the Atlantic Ocean. In America, it was presented as the people "possessed 'the right to assemble ... in their town halls, there to deliberate upon the public affairs." [8] While in France, it was not presented in the praxis but was a kind of passion in people's mind. Arendt thought the difference here played an important role in leading these revolutions into two ends. As the French people did not have the experience of practicing the public freedom, they misunderstood it with a kind of mass intoxication during the revolution. They considered that the public freedom maybe means people's being on the spot and stopped right there without building up a kind of Constitution but turned to solve the poverty of the people. Tocqueville also shared this idea with Arendt, as he described the French people during the revolution, he said, "the passion for liberty has frequently been extinguished again, and again revived. This will long be the case, for it is still inexperienced, ill regulated, easily discouraged, easily frightened away, easily overcome, superficial, and evanescent. Meanwhile, the passion for equality has retained its place at the bottom of the hearts it originally penetrated and linked with their dearest sentiments." [9] In comparison, American people's success is related to their pre-revolution praxis of the public freedom, as they have tasted it since they stepped onto the new continent. Arendt dated back to the history during which the colonies in America were founded to show how they formulated the "ward system", as Jefferson named [10], in which the people could discuss with each other and act together for their public aims. As they had already had the tradition of public freedom, they knew what they should do after the revolution, which, as Arendt articulated, was to build up a new power center that would transfer the old ruling-ruled system to a collective politics [11]. Then, in the new continent, owning public freedom was equal to owning power, and only when the people got into the public affairs, they could be said as sharing the happiness of freedom. In this way, the Constitution in American was to make sure this power-freedom relation. Therefore, the Constitution in one way constricted the central power by the principles of separation power, which could insure none of the person would take too much power and destroyed the system; in the other way, the Constitution also confirmed the importance of a central government in federalism but not confederacy, because the founding fathers found that without a strong central government, the loose relation among the states would cause impotence but not power. Thus, we could find that the America's praxis on public freedom is tightly related to a kind of new power principle. Arendt mainly illustrated the old ruling-ruled power principle and the new one through a comparison between two kinds of social contracts. The old social contract was established between people and their ruler, while the other was between every individual. By the first one, people channeled some of their power into the government to sum up for a more extensive power, and this power would be monopolized by the government, under which people would be ruled but protected. The second social contract could be seen as a mutual contract, which was based on reciprocity and presupposed equality, and "its actual content is a promise, and its result is indeed a 'society' or 'co-sociation'." Then, there would not be a ruler in this contract and the people should make decisions all together and protect each other by uniting [12]. Obviously, the power principle of America originated from the second social contract, which means the power was produced during the promises in the mutual progress. On the basic level, power resides in people and shared among people so that the ruling-ruled relationship would not exist; On the level of states, she articulated that "according to which (mutual contrast) constituted political bodies can combine and enter into lasting alliance without losing their identity." [13]

Before getting into the second factor, we had better refer to some other materials of Arendt, which could help us have a clearer understanding of the importance of the first one. The reason why Arendt considered the combination of power and freedom should be a great creation of American Revolution was because in her philosophy, freedom tightly related to human's actions and speeches. In Origin of Totalitarianism, she mentioned that, "[T]he very source of freedom is given with the fact of the birth of man and resides in his capacity to make a new beginning." [14] While, "beginning" inside the theory of Hannah Arendt was related to the action and speech of human, as Wolfhart Totschnig said in his article, action in Arendt's theory is in some way "synonymous with beginning" [15]. Therefore, in Arendt's theory, only insuring people's ability to take actions, could the freedom of them be guaranteed. What the public freedom in America had supplied was exactly a kind of system that encouraged and protected people's discussions and actions. Thus, it certainly would be put by Arendt in a such high position. 


\subsubsection{Political Authority from Founding Moment}

The second positive factor is that the authority of the state should come from the founding moment. She discussed in Chapter 5 of On Revolution that, in the western tradition, the authority of the constitutions always came from an absolute source, which could be described as "higher law" [16]. The French Revolution followed this "higher law" tradition by transferring the source of the law from the gods to the "general will". For example, when Robespierre dealt with the problem of the authority of law, he also sought to find an Immortal Legislator who could best represented the will of the people [17].

Arendt considered that the founding fathers in America, actually found another source could supply the authority to the constitution, which is the foundation of the State. This intention was articulated as learning from Roman Republic. As Arendt thought, "the very concept of Roman authority suggests that the act of foundation inevitably develops its stability and permanence, and authority in this context is nothing more or less than a kind of necessary 'augmentation' by virtue of which all innovations and changes remain tied back to the foundation which, at the same time, they augment and increase." [18] The American revolutionists had learnt this way to build the authority of their state. But what they applied into American politics was the inner logic but not the shape of Roman way, unlike their ancient teacher, they combined the authority with the founding moment by the Constitution but not senate. And, the implementor of the authority was the judiciary institutions, because American founding fathers thought it was the weakest in the political system and would not harm the power balance [19]. The process of augment, which was the necessary maintenance of the authority, reflected in the process of amending the constitution, which was articulated by Hannah Arendt as "the amendments to the Constitution augment and increase the original foundation of the American republic; needless to say, the very authority of the American Constitution resides in its inherent capacity to be amended and augmented." [20]

However, Arendt also considered that the American Constitution was braver and more radical than the traditional version in Roman Republic. Arendt noticed that in the words of the founding fathers, they never mentioned one of the stories about Roma's foundation, in which the foundation of Rome was a reestablishment of Troy. This choice implied that what the founding fathers wanted to rely on was the vigorous power of beginning itself. As they were the only ones who had succeeded in building up a Constitution for the public freedom, the success of the foundation itself had already offered strong authority to the Constitution and showed that it was the right one for maintaining the freedom [21]. Arendt furtherly illustrated this point as "what saves the act of beginning from its arbitrariness is that it carries its own principle within itself, or, to be more precise, that beginning and principle, principium and principle, are not only related to each other but are coeval." [22] Simpler, this articulation means that those beginners laid down the law of action for their followers and offspring.

\subsection{Negative Factors: Tradition of Absolute Source, Misusing of Compassion, and the Highlight of the Private Happiness}

\subsubsection{Tradition of Absolute Source}

The first negative factor was that the tradition of absolute source had remained in the revolution. Even not like the centuries under the emperor's ruling, in which the power and the authority was not owned by the same person or institution, the revolution's liberation to the people made these two things into one hand. As we have mentioned, the French people never have the experience of implementing the public freedom, and they considered being seen, being thought, and being taken care of was already a kind of attendance to the public freedom. Therefore, the basic logic of power in French Revolution was not changed, it was still under the old ruling-ruled model [23]. Then, it still required an absolute source to legitimatize the power of ruling. To solve this problem, the revolutionists following the philosophy of Rousseau and took his theory of "general will". As Rousseau himself had said, general will "always tends to public utility" and "is always rightful" [24]. So, the most important aim of those people in power was not to build up a Constitution in which the people could own the power and took actions, but to find out what should be the right way of reach the general will. They considered as Rousseau taught, once all of the individual interests were excluded, the general will would expose [25]. Therefore, the revolution became into a war between a revolutionist and himself or herself. By the way, if we think a bit further, we could find that the notion of general will had a strong theological color. As Critchley said, "The general will is transformed from God's supposed will to save all men into the human will insofar as one wills as a citizen." [26] The most important thing in this change was that the unreachable gap between political power and the will of god had been removed, by fighting their own interests, the rulers seemed like being able to get into the general will. In this way, selflessness, as the virtue of discarding one's own interests, did not only mean a high moral standard, but also meant the legitimacy of owning power. Therefore, as Arendt said, "the value of a policy may be gauged by the extent to which it will contradict all particular interests." [27] As a result, in the polity of "general will", we could find that, there would not be any space for the American style public freedom. The discussion became unnecessary, because what the people wanted was already known as long as the rulers followed general will. The most critical danger it left on French Revolution should be combined with the second factor we would talk soon. Simply speaking, the problem was that the possibility of reaching the general will in Rousseau's being selfless was a kind of misunderstanding. 


\subsubsection{Misusing of Compassion}

The second negative factor to French Revolution in Arendt's articulation was that the revolutionists' misusing of compassion as the way to reach selflessness. As Arendt had noticed that, in Rousseau's understanding, selflessness was articulated as "the capacity to lose oneself in the suffering of others, rather than active goodness." [28] Following, compassion as the ability to feel the suffering of others seemed like the ability of being selfless, and thus, became important in the revolution. However, Arendt thought that, the compassion understood by the revolutionist was actually the notion of pity. Compassion was a kind of ability that one was able to "be stricken with the suffering of someone else as though it were contiguous" [29], as understanding the sufferers not through the contents of the words and deeds but directly feeling what emotions inside their hearts. In this way, it was impossible for compassion directly working inside the area of politics, because no one could use this ability to different people in the same moment, therefore it would not able to formulated a co-action among the participants. Only Jesus can use compassion to all of the people by his divine ability, and in this reason, only the kingdom of him could be able to withdraw politics. He could directly feel the sorrow and needs of everyone and duel with all of these sufferings at the same time [30]. However, if we have a look on the revolutionists in France, what they did was feeling sorry for the sorrow that was imagined by themselves. The source of the sufferings was not every individual, but an abstract picture of the mass. Arendt called this inner motion as pity, which is a kind of emotion that "to be sorry without being touched in flesh" [31], and "can be enjoyed for its own sake, and this will almost automatically lead to a glorification of its cause, which is the suffering of others." [32] The most important harm that Arendt pointed out was that pity was a kind of emotion, which could only happen when the suffering was existing and had the inclination to glorify the sufferers and depreciate the happiness. When Robespierre brought pity into the revolution, his emotion was endlessly stirred by the misery of the poor people, which drove all his intensions onto solving poverty and left the aim of building up a Constitution far behind.

\subsubsection{Highlighting of Private Happiness}

The third negative factor was that seeking for private happiness would formulate a digestive force to the public freedom. Arendt mentioned how the immigration influenced the American society. She thought that the wave of people from Europe to America happened in the 19th century and the 20th century changed the attitude of American to the public affairs [33]. For the people who suffered misery in Europe, abundance and endless consumption were their aims of life. The happiness and importance of attending the public lives could not be understood by them. Therefore, companying with more and more immigration to America, the fatal passion for the sudden rich became the main content of the American dream. Under this circumstance, there are two different kinds of minds living on the land of America, which are as Arendt said, America was "not only the "land of liberty, the seat of virtue, the asylum of the oppressed,' but also the promised land of those whose conditions hardly had prepared them for comprehending either liberty or virtue." [34]

\section{REFLECTION}

From the former parts, we have sketched an outline of what factors should the "ideal state" of Hannah Arendt possess or avoid. However, in her articulations about these factors, there are still some problems deserving furtherly investigation.

The first question is: what is the social basis of her political thoughts in On Revolution? Firstly, we can notice that, she had a strong inclination to take the United State in its original period as the prototype of her ideal state. The most important reason of it was that she considered the American people at that time could be able and willing to attend the public affairs. However, the reason why it is possible for them has its critical economic root: the slavers had done all the jobs to maintain their life and richness. Actually, most of Arendt's ideal polities have this characteristic. In Human Condition, when she refer the ancient Greek to illustrate her idea of politics, she also mentioned that, the citizens were free from the necessity, due to the labor of their slavers [35]. These sentences here definitely aim at demonstrating Arendt was a supporter of slavery, but to show the participants in her idea of politics were always free from the bother of maintaining life, which could make sure they could get rid of the private interests and focusing on the public affairs. Therefore, it implies that Arendt's politic could happen in two ways, either the material life for people is totally prosperous or the material needs of people are extremely low as they would spend very little time to fulfill their biotic necessity. Arendt certainly is the supporter of the former one, as she stressed the importance of technology and science for her idea of politics. If we do not be that strict on the economic conditions, then another problem will happen, which is the requirement of people's moral standard would sharply be pulled up. It will require the participants selflessly cut all their private attributes when they step into the public sphere.

The second question is: when private happiness and public freedom fell into contradiction, what can we do? As she mentioned that, when those people get into the new continent, their vigorous ambition in becoming rich had fiercely attacked the root of the American Constitution. However, even Arendt herself did not give a useful solution to this situation. She had mentioned to cultivate the public spirit and build up the public systems to help people formulate the ability and will to attend public life [36]. But the real problem is that there would always be people only focusing on their own stuff, this is not due to the education or customs, but due to human nature. In the history, even 
the golden days of the collective political life in ancient Athens, the dismissing power inside it were not weak [37]. Besides, if we just keeping running the public affairs by voluntary participating, then how could we make sure the decisions would obtain the agreement of those silent ones? Without their agreement but implementing the decision would trap the regime into the situation of ruling-ruled model.

The third question is: how to solve the relationship between the self-organized committees and the whole state? This problem was also raised by Arendt herself, when she considered history of the revolutions. As she mentioned, in all of the revolution, the state and the local committees would always fell into contradictions and the state would always cancel the existence of the committee [38]. Arendt's attitude of course inclined to the latter; she considered the control from the central government represented a kind of destroy to the new power principles. Again, her basic assumption of the world was ideal when she talked about this. In her articulation, the only thing people need to consider is to take actions to fulfill their glories. However, in the modern era, there are still conflicts among different countries. In some areas, law of the jungle still played a significant role. Though, as Arendt have said, the escalating of military has helped us lower and lower the possibility of large wars, the competitions among countries have much more forms, such as financial war, ideology war, and information war [39]. All this situation also left a necessity for the weak countries to have a strong government, which could organize the resource together to maintain the survival of their nations.

\section{CONCLUSION}

From Arendt's articulation of an "ideal state", we could see her sincerity on thinking about the suitable conditions of people's freedom. Ideally speaking, she was totally right, all of the human beings should have the power to attend the process of decision making and all of the human beings should enjoy the chance of displaying his or her talent to the fellows and devote it to the glories of human beings. Though she never had a temptation to give an answer, which left a lot of debates and challenges to her theories, I think the high moral standing of Arendt preciously reflects here. She is so prudent that she was not willing to give out a solution hastily as she knew what the power of political articulation would leave to the reality.

The dilemma of Arendt also belongs to all of us in the current days. On one side, there is the ideal world that all of the human beings would finally share a sweet life with each other, none of us has to consider the dangers of war, and we could totally focus on how to fulfill our freedom and immortality. On the other side, there is the realistic current situation that great powers dominate the world order, big capitals control the societies, nations and nations are against each other, races and races still have discriminations, poverty and starvation are still happening in a large scale around the world. We are here, but we want to go there. Including Hannah Arendt, many former philosophers have sketched a blueprint for us, and in now days, we have the destiny to make a little progress on fulfilling this golden dream. Marx had said, "The philosophers have only interpreted the world in various ways. The point, however, is to change it." After a long revolutionary history in last centuries, I think we should say it as, "The point, however, is to change it, prudently."

\section{REFERENCES}

[1] Badiou, A., Gauchet, M. (2016) What Is To Be Done? A Dialogue on Communism, Capitalism, and the Future of Democracy. Moderated by Martin Dura and Martin Lergos, translated by Susan Spitzer. Polity Press, Cambridge. pp.106.

[2] Pew Research Center. (2015) Beyond Distrust: How Americans View Their Government. https:/www.peoplepress.org/2015/11/23/1-trust-in-government-1958-2015/

[3] Sultany, N. (2017) Law and Revolution: Legitimacy and Constitutionalism After the Arab Spring. Oxford University Press, Oxford. pp.1-4.

[4] Arendt, H. (1958) The Human Condition. The University of Chicago Press, Chicago. pp.195

[5] Wellmer, A. (2000) Arendt On Revolution, in: Dana, V (eds), The Cambridge companion to Hannah Arendt. Cambridge University Press, Cambridge. pp220-241.

[6] Arendt, H. (1990) On Revolution. Penguin Books Ltd, London. pp.17.

[7] Wellmer, A. (2000) Arendt On Revolution, in: Dana, V (eds), The Cambridge companion to Hannah Arendt. Cambridge University Press, Cambridge. pp220-241.

[8] Arendt, H. (1990) On Revolution. Penguin Books Ltd, London. pp.118.

[9] Tocqueville, A.D. (2010) The Old Regime and the French Revolution. Translated by John Bonner, Dover Publications, New York. pp.255

[10] Caivano, D. (2019) The Radical Democratic Thought of Thomas Jefferson: Politics, Space, \& Action. PH.D. Thesis, York University, Toronto. pp.95-146, https://yorkspace.library.yorku.ca/xmlui/bitstream/handle/ 10315/36660/Caivano_Dean_C_2019_PhD.pdf?sequence $=2 \&$ isAllowed $=\mathrm{y}$

[11] Arendt, H. (1990) On Revolution. Penguin Books Ltd, London.pp.149.

[12] Ibid, pp. 170 .

[13] Ibid, pp.171

[14] Arendt, H. (1966) Origins of Totalitarianism, Harcourt, Brace and World, New York. pp.466 
[15] Wolfhart, T. (2017) Arendt's Notion of Natality an Attempt at Clarification. Ideas y Valores, vol. LXVI, no. 165, September-December 2017. pp. 327-346. DOI:10.15446/ideasyvalores.v66n165.55202

[16] Arendt, H. (1990) On Revolution. Penguin Books Ltd, London.pp.161.

[17] Ibid, pp.181.

[18] Ibid, pp.202.

[19] Ibid, pp.199.

[20] Ibid, pp.202.

[21] Gottsegen, M.G. (1994) The Political Thought of Hannah Arendt. State University of New York Press, New York. pp.116.

[22] Arendt, H. (1990) On Revolution. Penguin Books Ltd, London. pp. 212.

[23] Schmidt, V.A. (1991) Democratizing France: The Political and Administrative History of Decentralization, Cambridge University Press, Cambridge. pp.10-40. DOI: https://doi-

org.easyaccess2.lib.cuhk.edu.hk/10.1017/CBO978051166 4229

[24] Rousseau, J.J. (2012) Of the Social Contract and Other Political Writings. Edited by Christopher Bertram, translated by Quintin Hoare. Penguin Books, London. pp.32.

[25] Arendt, H. (1990) On Revolution. Penguin Books Ltd, London. pp.79.

[26] Critchley, S. (2012) The Faith of the Faithless: Experiments in Political Theology. Verso, London. pp.107.

[27] Arendt, H. (1990) On Revolution. Penguin Books Ltd, London. pp.79.

[28] Ibid, pp.81.

[29] Ibid, pp.85.

[30] Young, S.C. (2004) Mission of compassion: Jesus as the eschatological Davidic Shepherd in Matthew's Gospel. Ph.D. Thesis, Trinity Evangelical Divinity School, Deerfield. pp.1-7.

[31] Arendt, H. (1990) On Revolution. Penguin Books Ltd, London. pp.85.

[32] Ibid, pp.89.

[33] Ibid, pp.138.

[34] Ibid, pp.139.

[35] Canovan, M. (1978) The Contradictions of Hannah Arendt's Political Thought. Political Theory, vol. 6, no. 1 February 1978. https://www.jstor.org/stable/190883

[36] Biesta, G. (2010) How to Exist Politically and Learn from It: Hannah Arendt and the Problem of Democratic Education. Teachers College Record, 2010, Vol.112(2). pp.556-575

[37] Chou, M. (2014) Democracy Against Itself: Sustaining an Unsustainable Idea. Edinburgh University Press, Edinburgh. pp.24-49. https://www.jstor.org/stable/10.3366/j.ctt14brxsq

[38] Arendt, H. (1990) On Revolution. Penguin Books Ltd, London. pp.215-281.

[39] Badiou, A., Gauchet, M. (2016) What Is To Be Done? A Dialogue on Communism, Capitalism, and the Future of Democracy. Moderated by Martin Dura and Martin Lergos, translated by Susan Spitzer. Polity Press, Cambridge. pp.105-132. 